\section{Original} Article

\begin{tabular}{|l|}
\hline Access this article online \\
\hline Website: \\
www.ajobe.org \\
\hline DOI: \\
10.4103/1817-7417.123080 \\
\hline Quick Response Code: \\
\hline
\end{tabular}

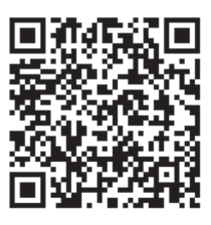

Address for correspondence: Rose Catacutan,

School of Humanities and Social Sciences, Strathmore University, Ole Sangale Road, Madaraka Estate, P.O. Box 59857, 00200, City Square, Nairobi, Kenya.

E-mail: rcatacutan@strathmore.edu

\title{
Education in virtues as goal of business ethics
} instruction

\section{Rose Catacutan}

Department of Philosophy, School of Humanities and Social Sciences, Strathmore University, Nairobi, Kenya

\author{
ABSTRACT
}

The moral development paradigm underlying a particular business ethics curriculum design plays a significant role in determining the goals of business ethics instruction. Concretely, the view of moral development advanced by cognitive developmental psychology that dominates business ethics literature identifies moral development with cognitive processes, but disregards educating students in virtues. The aim of the present paper is to propose an alternative paradigm of moral development to that of cognitive developmental psychology and presents Aquinas' view of moral development as a suitable framework for a curriculum design that focuses on virtues as a possible goal of business ethics instruction.

Key words: Goals, moral development, teaching business ethics, Thomas Aquinas, virtues

\section{INTRODUCTION}

It is widely accepted that the purpose of teaching ethics is of a practical nature, that is, ethics courses are expected to foster and develop the moral compass of business students. By attending ethics courses provided in business schools, it is presumed that students will acquire certain cognitive, behavioural and managerial competencies that will enable them to act with integrity as professionals in the future (Rossouw, 2004). This idea, however, is being challenged with the collapse of the world's economic and financial systems at a time when business ethics teaching is presumably at its peak among the best schools in Europe and America. In a bid to reclaim public trust, top business schools have recently undertaken significant reforms affecting the curricula and the leadership of their schools, namely, increasing the number of ethics courses offered in the curriculum, altering the timing of course offerings to include younger students, appointing business faculty with expertise in ethics to deanship positions and engaging faculty members from other disciplines to support institutional thrust towards business ethics education (Strauss, 2010; Stonington, 2011). Regrettably, despite these efforts, criticism against the teaching of business ethics continues unabated. Common among critics of business ethics education is the claim that a person's character is normally formed at a much earlier age and that teaching ethics to adult graduate school students is not likely to have much impact on their moral development (Garten, 2005; Korn, 2013). Interestingly, heads of business schools concur with their critics in this regard, but argue that business ethics teaching continues to be relevant, because ethics courses at least aid in the development of students' moral reasoning to make correct judgments over a wide range of highly complex moral issues in the field of business. From this perspective, the goal of ethics education is construed as primarily directed at and limited to the development of moral reasoning, or the cognitive dimension of moral development reminiscent of the theories on moral development advanced by $20^{\text {th }}$ century cognitive psychologists Jean Piaget, Lawrence Kohlberg and James Rest.

This paper argues that the moral development paradigm underlying a particular business ethics curriculum design plays an important role in the determination of the aims of business ethics instruction. Until date, a number of studies have been done on the goals of business ethics instruction. Among the possible aims of business ethics teaching, a few scholars have explicitly proposed the virtues or character education of students as its primary goal (Hartman, 1998; Mele, 2005; Mintz, 1996). The majority, however, 
reflect the view of moral development advanced by cognitive developmental psychology. Common among these studies is their focus on the cognitive processes of moral reasoning and moral awareness as aims of business ethics education, but with significant disregard for education in virtues among its goals (Felton and Sims, 2005; McDonald, 2004; Ritter, 2006; Waples et al., 2009; Williams and Dewett, 2005, Sims, 2002). This trend stands in contrast to numerous studies in business ethics literature that place great emphasis on the need for virtues in business practice and management.

Research on the virtues in business ethics literature began in the early 1990s with attempts by scholars to refute the then widely-held individualistic notions of business and corporations as amoral and profit-maximizing entities (Ewin, 1995; Hosmer, 1994; Koehn, 1992; Koehn, 1995; Shaw and Corvino, 1996; Solomon, 1992; Solomon, 1993;).

In his ground-breaking studies, Solomon (1992; 1993) proposed the need to re-examine the nature and purpose of business enterprises from the perspective of Aristotelian ethics, with its emphasis on excellence or virtue as the essential component of the good life, both at the individual and the corporate level. Subsequent research focused on exploring the core virtues relevant to business (Hartman, 1998; Murphy, 1999), the integration of virtues in management practice (Arjoon, 2000; Flynn, 2008; Mele, 2003) and the role of virtues in decision-making (Argandoña, 2007; Mele, 2010). Research on the virtues in business ethics was also extended to Aristotle's commentators, such as Thomas Aquinas and Alasdair MacIntyre (Arjoon, 2006; Mele, 2009; Moore, 2002), as well as to neo-Thomistic scholars, such as Josef Pieper (Flynn, 2008) and Jacques Maritain (Acevedo, 2012).

Two divergent trends in business ethics literature with respect to the virtues can be identified. On one hand, studies concerning the goals of business ethics instruction that predominate business ethics literature indicate a preference for the moral development paradigm espoused by cognitive developmental psychology, which implicitly rules out the possibility of educating students in virtues and emphasizes instead the development of the cognitive processes of moral reasoning and moral awareness as plausible aims of business ethics teaching. On the other hand, studies concerning the virtues in business ethics literature have experienced steady growth over the years, which is a clear indication of business ethics scholars' sustained interest to embed virtue ethics both in business theory and practice. The aim of the present paper is to address this conflict and propose an alternative view of moral development that could serve as a framework in establishing the goals of business ethics instruction. It suggests that Thomas Aquinas - considered as the main commentator of Aristotle (MacIntyre, in Mele, 2005) - provides a more comprehensive concept of moral development than that advanced by cognitive developmental psychology and therefore serves as a suitable framework for a curriculum design that focuses on students' education in virtues as a possible goal of business ethics instruction.

\section{The concept of moral development in cognitive developmental psychology}

Theories on the moral development of man can be traced back to the beginnings of Western civilization, specifically the teachings of the ancient Greek philosophers such as Socrates, Plato and Aristotle. This, however, was not the case in the field of psychology, where most of the research on moral development formally took shape in the late $20^{\text {th }}$ century, with the works of cognitive developmental psychologists Jean Piaget, Lawrence Kohlberg and James Rest. Jean Piaget (1932/1956) pioneered research in the field and established that moral development is a function of cognitive development, evidenced by older children tending to manifest a more advanced form of moral reasoning than younger ones. His theory established three stages of moral development, namely the pre-moral stage typical of children below 4 years of age and the moral stages of heteronomous and autonomous reasoning characteristic of children aged 4 years of age and above. He found that children typically begin to exhibit moral awareness upon reaching the age of four, but that the understanding of rules tends to vary according to different age groups. Moral reasoning of children aged four to seven is characterised by heteronomous reasoning or a way of understanding rules as being fixed and unchangeable and that these should be strictly obeyed. However, moral reasoning of older children, aged 7-11, is typified as autonomous reasoning or a manner of viewing moral rules as being arbitrary and fluid and that these can be changed as the need arises.

Building on and extending Piaget's research to young adults, Kohlberg(1969/1984) proposed a six-stage sequence of moral development, grouped into three levels, namely the pre-conventional, the conventional and the post-conventional stage. In each level, moral development is characterised by the type of moral reasoning used when individuals behave morally, ranging from self-interest and fear of punishment at level one, concern for others at level two and sense of justice and respect for rights at level three. Kohlberg further claimed that moral reasoning that appeals to rights and justice corresponds to the most advanced form of moral development. Although Piaget and Kohlberg focused on moral reasoning as an exclusive determinant of moral behaviour, Rest proposed the four component model, which posits that moral development is a function of four mental processes: Moral sensitivity or the ability to interpret the moral context in which one's actions unfold; moral judgment, or the ability to judge whether an action is morally right or wrong; moral motivation, or the ability to prioritise moral values over personal values; and, finally, moral character or the ability to have strong convictions and carry out good 
actions with courage and persistence, despite the presence of obstacles (Rest, 1980;Bebeau, Rest, and Narvaez (1999).

Despite its popularity, the view of moral development advanced by cognitive developmental psychology has been criticised by several circles. Critics of Kohlberg, for instance, claim that his theory reflects a strong preference for Rawl's neo-Kantian philosophy (Wren, 1990 cited in Rest, Narvaez, Thoma and Bebeau, 2000) and also a bias for men as against women, whose mode of thinking is generally oriented towards caring and connectedness rather than justice (Gilligan, 1982 cited in Rest, Narvaez, Thoma and Bebeau, 2000). Other critics cite empirical studies that found that, contrary to Kohlberg's findings, evidence of adults reaching the principled level or the highest stage of moral reasoning is rare. Finally, other opposing voices highlighted the affinity of cognitive moral development theories with Socratic intellectualism (Feak, 1979), a position in which virtue is identified with knowledge of the good, such that "he who knows the good chooses the good" (Kohlberg, 1970, cited in Feak, 1979).

\section{Thomas Aquinas' concept of moral development} This paper argues that Aquinas(1273/1947) offers a more comprehensive view of moral development than that of cognitive developmental psychology, which therefore serves as a suitable framework for a curriculum design that focuses on students' education in virtues as a possible goal of business ethics instruction. Moral development in Aquinas' theory is a complex process that involves not only the intellect through the development of the cognitive processes, such as moral reasoning and awareness, but also of the will through the development of virtues. This section will provide a discussion of Aquinas' view of moral development, specifically the ways in which Aquinas relates virtue as a quality of the will rather than of the intellect, the characterisation of virtue as an act of choice and the emphasis he places on the role of virtues in moral reasoning. Some implications of Aquinas' view of moral development on business ethics instruction will also be mentioned.

In contrast with the claims of cognitive development theories, moral development, according to Aquinas, is not simply a function of the mind to make judgments, prioritise values and formulate strong convictions, but it is also a function of the will to which the human capacity to intend and choose is attributed. There are three ways in which Aquinas relates moral development to the will: First, in defining moral virtue as a quality of the will; second, in relating moral virtue to choice; and, lastly, in upholding the influence of the virtues on moral reasoning.

Aquinas distinguished his view of moral development from cognitive development psychology by identifying virtue as a quality of the will, rather than of the intellect. In his discussion on whether the intellect can be the subject of virtue (ST I-II, q. 56, a. 3), Aquinas argued that any habit that simply confers an aptitude to act, but not the right use of that aptitude, could not be considered a virtue in the strict sense. Such would be the case of the habit of speech, which gives somebody an aptitude for speaking correctly, but not necessarily an aptitude for speaking respectfully and charitably towards others. For Aquinas, virtues have a two-fold characteristic: They make one's actions good and they make the subject or the possessor of virtues good. The virtue of justice, for instance, can be considered a real virtue, because it does not only confer a certain aptitude to carry out just actions, but it also makes the one acting a just man. Having identified virtue as a capacity to perform good actions, he then attributes virtues to the human will:

And if man do well actually, this is because he has a good will. Therefore the virtue which makes a man to do well actually, and not merely to have the aptness to do well, must be in the will itself or in some power as moved by the will (ST I-II, q. 56, a. 3).

For Aquinas, the question of a person's goodness depends to a great extent on his use of his capacities or powers, or the way in which he 'moves them to their acts' by his will (Brock, 1995). In identifying virtues with the will rather than the intellect, he rejects the view of virtues advanced by cognitive developmental psychology being a state of mind or a strong sense of conviction as articulated in the construct of moral character, the fourth component of Rest's model (Osorio, 2010).

Another way in which Aquinas' view on moral development differs from cognitive development psychology theories is the identification of moral virtue with the act of choice, one of the principal acts of the will. In analysing the structure of the voluntary act, Aquinas presents a human act as a complex interplay of several processes that are both cognitive and volitional, distinguishing, on one hand, deliberation and judgment as acts of the intellect and, on the other hand, intention and choice as acts of the will (ST I-II, q. 12 - q. 16). Each process, in turn, is distinguished from the other by virtue of their role or function in human agency. In every action, an agent formulates an intention regarding the end or goal he wants to strive for, deliberates on the means to achieve his end, makes a judgment on and chooses the most appropriate action, and finally executes the action he has chosen. Hence, contrary to the position of Socratic intellectualism, moral development in Aquinas is not identified with the mere capacity for moral judgment or moral reasoning. Moral development is a much more complex process, involving choice of a good expressed in conduct: To enact morally good actions, it is not enough to know the good, but it is also necessary to choose and do it (McInerny, 1997).

Finally, the distinction between the moral development 
paradigm of Aquinas and that of cognitive developmental psychology is found in Aquinas' emphasis on the role of virtues in moral reasoning, an idea that forms part of his theory on the interconnection of virtues (ST I-II, q. 65, a. 1). In a nutshell, the theory claims that there exists a reciprocal influence between prudence and moral virtues, reason and will, moral reasoning and virtues in moral activity. Pieper (1966) described this interconnection in saying that "only the prudent man can be just, brave and temperate; yet he who is not already just, brave and temperate cannot be prudent." According to this theory, the virtues of justice, fortitude and temperance cannot exist without the virtue of prudence. As a habit of right choice, moral virtues stand in need of prudence, which guarantees correct reasoning in moral matters. In this sense, no moral virtue can be without prudence, because careful deliberation and judgment play a significant role in discerning whether one's action or another person's action is just or unjust, audacious or cowardly and temperate or intemperate.

Conversely, the theory posits that the virtue of prudence stands in need of the virtues of justice, fortitude and temperance, because vice corrupts the principles of reason (Aquinas, 1993; Commentary on The Nicomachean ethics, Book VI, 5) and therefore leads to faulty reasoning in moral matters. For Aquinas, moral virtues play a role in developing moral reasoning; as qualities of the will, moral virtues reinforce human tendencies toward the good, which, in turn, facilitate correct reasoning in moral matters. For instance, a person who strives for justice as a moral good is more likely to reason according to principles of justice and consequently act justly in all his actions. Aquinas' theory on the interconnection of virtues suggests that behind every failure to act ethically is a failure, not only in the moral reasoning process, but also a failure in the practice of the virtues. As McInerny put it:

The problem of morality is both a cognitive and an existential one. That is, we must both know what it is we ought to do and then act in accord with that knowledge (1997: 120).

Understanding the influence that moral virtues exert on moral reasoning is essential in framing the objectives of business ethics teaching. Hence, contrary to the view of cognitive developmental psychology, the moral development paradigm of Aquinas underscores the inadequacy of a curriculum design that does not purposely set students' education in virtues as a goal of business ethics instruction.

Implications in setting the goals of business ethics instruction

The moral development paradigm underlying any curriculum design has a significant influence in the determination of the goals of business ethics instruction. Concretely, the question as to whether students' education in virtues could be considered a likely goal for business ethics teaching is inevitably linked to the moral development paradigm that is held or espoused. The understanding of whether virtues exist or not, what virtues are and how they can be acquired are important components of business ethics curriculum design.

Proponents of cognitive developmental psychology, for instance, have formally rejected the formulation of educational goals aimed at education in virtues. Specifically, Kohlberg criticised character education programmes aimed at teaching virtues, arguing that such approaches constitute a form of indoctrination (Kohlberg and Hersh, 1977). He also claimed that virtues are of no interest to cognitive developmental psychology, describing virtues as nothing but character traits that are not stable enough for a person to have over a period of time (Sanderse, 2012). Implicit in this critique of Kohlberg is a concept of moral development that significantly differs from that of Aquinas, which, as previously discussed, relates moral development, not only to cognitive development, but also to the development of the will through the virtues. According to Aquinas, virtues are habits and, as such, signify something stable and lasting that confers predictability in actions; they are not just a set of fleeting attitudes that result from external compliance to some conventional rule or from sheer imitation of another person's actions. Further, virtues cannot be acquired through sporadic actions, because habits presuppose stability of dispositions and such stability is not possible without consistent repetition of good actions. In conceptualising virtues as qualities of the will, Aquinas also suggested that the human capacity to accomplish the good is something that originates from a power intrinsic in man. Consequently, virtues cannot be acquired by blind indoctrination or by instinctive repetition, as both presuppose the elimination of deliberation and choice; hence, from the perspective of Aquinas' concept of moral development, virtues can only be acquired when one freely or voluntarily desires and chooses to practise them. Further, the intrinsic link that virtue has with the act of choice also suggests that man has an inherent capacity to enact positive changes in a moral life. Therefore, contrary to popular claims that a person's character remains unalterable upon reaching adulthood, the moral development framework of Aquinas asserts that moral change is within everybody's reach through the act of choice.

In summary, it can be said that the moral development paradigm used in curriculum design influences, to a great extent, the determination of the goals of business ethics teaching, because it is bound to the more important questions related to what virtues are, whether virtues exist or not and how virtues can be acquired. The moral development of Aquinas is therefore proposed as an alternative framework for establishing students' 
education in virtues as a possible goal for business ethics instruction, given the inherent limitations of the moral development paradigm advanced by cognitive developmental psychology.

\section{Closing remarks}

Current debates on whether educating students in virtues could be considered a possible goal of ethics instruction depends, to a large extent, on the moral development paradigm that is espoused. The view of moral development advanced by cognitive developmental psychology that currently dominates business ethics literature identifies moral development with cognitive processes of moral awareness and moral reasoning, but disregards education in virtues as a possible goal for ethics instruction. This paper has presented two conflicting perspectives on moral development and advanced several arguments in favour of Aquinas' moral development paradigm as an alternative framework to that of cognitive developmental psychology in framing the goals of business ethics instruction.

\section{REFERENCES}

Acevedo, A. (2012). Personalist business ethics and humanistic management: Insights from Jacques Maritain. Journal of Business Ethics, 105, 197-219.

Aquinas, St. Thomas. (1273). Summa Theologiae, transl. (1947) by Fathers of the English Dominican Province. New York, NY: Benziger Brothers.

Aquinas, St. Thomas. (1993). Commentary on Aristotle's the Nicomachean Ethics, transl. by C.I. Litzinger. Notre Dame, IN: Dumb Ox.

Argandoña, A. (2007). Integrating ethics into action theory and organizational theory. Journal of Business Ethics, 78, 435-46.

Arjoon, S. (2000). Virtue theory as a dynamic theory of business. Journal of Business Ethics, 28, 159-78.

Arjoon, S. (2006). Ethical decision-making: A case for the triple font theory. Journal of Business Ethics, 71, 395-410.

Bebeau, M., Rest, J. R., and Narvaez, D. (1999). Beyond the promise: A perspective on research in moral education. Educational Researcher, 28, 18-26.

Brock, S. (1995). What is the use of usus in Aquinas' psychology of action? In B. Bazan., E. Andujar., and L. Sbrocchi (Eds.). Moral and political philosophies in the middle ages. Ottawa: Legas; 654-64.

Ewin, R. (1995). The virtues appropriate to business. Business Ethics Quarterly, 5, 833-42.

Feak, M. (1979). Moral development and its explanation: Kohlberg's structuralism. Master's thesis, McMaster University. [Online]. Available from: http://www.digitalcommons.mcmaster.ca/opendissertations/293. [Last accessed on 10 July 2013].

Felton, E, and Sims, R. (2005). Teaching business ethics: Targeted outputs. Journal of Business Ethics, 60, 377-91.

Flynn, G. (2008). The virtuous manager: A vision for leadership in business. Journal of Business Ethics, 78, 359-72.

Garten, J. (2005). B-Schools: Only a C+in ethics. Schools need to do much more to help students make moral choices. [Online] Available from: http://www.businessweek.com/magazine/content/05_36/b3949138. htm. [Last accessed on 1 July 2013].

Hartman, E. (1998). The role of character in business ethics. Business Ethics Quarterly, 8, 547-59.

Hosmer, L. (1994). Why be moral? A different rationale for managers. Business Ethics Quarterly, 4, 191-204.
Koehn, D. (1992). Toward an ethic of exchange. Business Ethics Quarterly, 2, 341-55.

Koehn, D. (1995). A role of virtue ethics in the analysis of business practice. Business Ethics Quarterly, 5, 533-9.

Kohlberg, L. (1984). Stage and sequence: The cognitive-developmental approach to socialization. Essays on moral development: The psychology of moral development. Vol. 2, (pp. 1-169). San Francisco: Harper and Row. (Original Work Published 1969).

Kohlberg, L., and Hersh, R. (1977). Moral development: A review of the theory. Theory Into Practice, 16, 53-9.

Korn, M. (2013). Does an 'A' in ethics have any value? [Online]. Available from: http://www.online.wsj.com/article/SB100014241278873247610045 78286102004694378.html. [Last accessed on 1 July 2013].

McDonald, G. (2004). A case example: Integrating ethics into the academic business curriculum. Journal of Business Ethics, 54, 371-84.

Mclnerny, R. (1997). Ethica Thomistica: The moral philosophy of Thomas Aquinas. Washington D.C.: Catholic University of America Press.

Mele, D. (2003). The challenge of humanistic management. Journal of Business Ethics, 44, 77-88.

Mele, D. (2005). Ethical education in accounting: Integrating rules, values and virtues. Journal of Business Ethics, 57, 97-109.

Mele, D. (2009). Integrating personalism into virtue-based business ethics: The personalist and the common good principles. Journal of Business Ethics, 88, 227-44.

Mele, D. (2010). Practical wisdom in managerial decision-making. Journal of Management Development, 29, 637-45.

Mintz, S. (1996). Aristotelian virtue and business ethics education. Journal of Business Ethics, 15, 827-38.

Moore, G. (2002). On the implications of the practice-institution distinction: Macintyre and the application of modern virtue ethics to business. Business Ethics Quarterly, 12, 19-32.

Murphy, P. (1999). Character and virtue ethics in international marketing: An agenda for managers, researcher and educators. Journal of Business Ethics, 18, 107-24.

Osorio, A. (2010). Insuficiencia de los constructos psicologicos en la educacion del altruism. Educacion, 13, 125-38.

Piaget, J. (1956). The moral judgment of the child. (M. Gabain Transl.). New York, NY: Free Press; (Original work published 1932).

Pieper, J. (1966). The four cardinal virtues. Notre Dame, IN: University of Notre Dame Press.

Rest, J. (1980). Moral judgment research and the cognitive-developmental approach to moral education. The Personne/ and Guidance Journal, 58, 602-5.

Rest, J. R., Narvaez, D., Thoma, S. J., and Bebeau, M. J. (2000). A neo-Kohlbergian approach to morality research. Journal of Moral Education, 29, 381-96.

Ritter, B. A. (2006). Can business ethics be trained? A study of the ethical decision making process in business students. Journal of Business Ethics, 68, 153-64.

Rossouw, D. (2004). Developing business ethics as an academic field. Ben-Africa:Johannesburg: BEN-Africa.

Shaw, B. and Corvino, J. (1996). Hosmer and the "why be moral?" question. Business Ethics Quarterly, 6, 373-83.

Sims, R. (2002). Teaching business ethics for effective learning. Westport, CT: Quorum.

Solomon, R. (1992). Corporate roles, personal virtues: An Aristotelian approach to business ethics. Business Ethics Quarterly, 2, 317-39.

Solomon, R. (1993). Ethics and excellence. Oxford: Oxford University Press. Stonington, J. (2011). B-schools' new mantra: Ethics and profits. [Online]. Available from: http://www.businessweek.com/business-schools/ bschools-new-mantra-ethics-and-profits-11102011.html. [Last accessed on 1 July 2013].

Strauss, V. (2010). Ethics expert to head Harvard Business School. [Online]. Available from: http://www.voices.washingtonpost.com/answer-sheet/ higher-education/ethics-expert-to-head-harvard.html. [Last accessed on 1 July 2013].

Waples, E. P., Antes, A. L., Murphy, S. T., Connelly, S., and Mumford, M. D. (2009). A meta-analytic investigation of business ethics 
instruction. Journal of Business Ethics, 87, 133-51.

Williams, S., and Dewett, T. (2005). Yes, you can teach business ethics: A review and research agenda. Journal of Leadership and Organizational Studies, 12, 109-20.
How to cite this article: Catacutan R. Education in virtues as goal of buisness ethics instruction. Afr J Bus Ethics 2013;7:20-5.

Source of Support: Nil, Conflict of Interest: None declared

\section{AUTHOR}

Rose Catacutan is a lecturer of Business Ethics in the School of Humanities and Social Sciences at Strathmore University, Nairobi Kenya. Her research is in the areas of accounting ethics, business ethics education, and corporate social responsibility. 
Reproduced with permission of the copyright owner. Further reproduction prohibited without permission. 